\title{
Age and Condition of Juvenile Catostomids in Clear Lake Reservoir, California
}

Open-File Report 2013-1188 



\section{Age and Condition of Juvenile Catostomids in Clear Lake Reservoir, California}

By Summer M. Burdick, U.S. Geological Survey, and Josh Rasmussen, U.S. Fish and Wildlife Service

Open-File Report 2013-1188

U. S. Department of the Interior

U. S. Geological Survey 


\section{U. S. Department of the Interior \\ SALLY JEWELL, Secretary}

\section{U. S. Geological Survey \\ Suzette M. Kimball, Acting Director}

U. S. Geological Survey, Reston, Virginia: 2013

For more information on the USGS-the Federal source for science about the Earth, its natural and living resources, natural hazards, and the environment, visit $h t t p: / / w w w$. usgs. gov or call 1-888-ASK-USGS.

For an overview of USGS information products, including maps, imagery, and publications, visit $h t t p: / / w w w . u s g s . g o v / p u b p r o d$

To order this and other USGS information products, visit http://store.usgs.gov

Suggested citation:

Burdick, S.M., and Rasmussen, J., 2013, Age and condition of juvenile catostomids in Clear Lake Reservoir, California: U.S. Geological Survey Open-File Report 2013-1188, 20 p.

Any use of trade, product, or firm names is for descriptive purposes only and does not imply endorsement by the U.S. Government.

This work was funded by the Ruby Pipeline Corporation and the U.S. Geological Survey and was completed in cooperation with the U. S. Fish and Wildlife Service. The findings and conclusions in this article do not necessarily represent the views of the U.S. Fish and Wildlife Service.

Although this report is in the public domain, permission must be secured from the individual copyright owners to reproduce any copyrighted material contained within this report. 


\section{Contents}



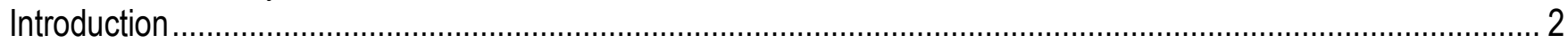

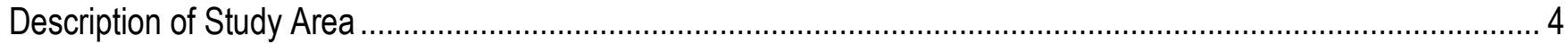

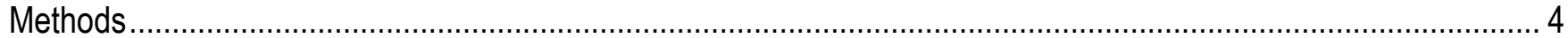

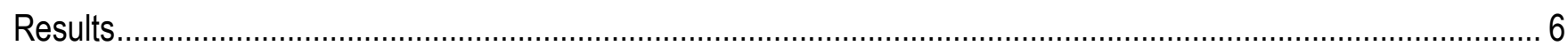

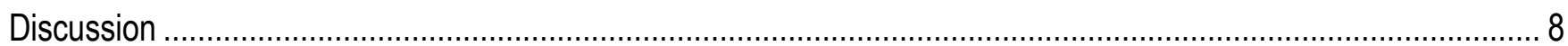

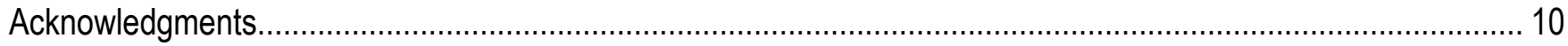

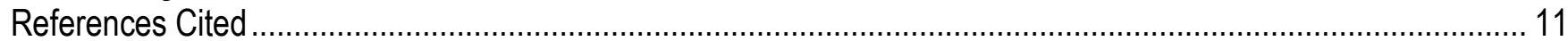

\section{Figures}

Figure 1. Map showing sampling locations in Clear Lake, California (Modoc County), and its tributaries

Figure 2. Boxplots showing standard length of suckers collected in Clear Lake, California (Modoc County)

by annuli counted on fin rays. Boxplots show the 25 th, 50 th, and 75 th percentile

Figure 3. Graph showing length frequency for juvenile suckers captured in Clear Lake, California (Modoc County) in 2012

Figure 4. Graph showing weekly length frequency for juvenile suckers captured in Clear Lake, California (Modoc County) in 2012

Figure 5. Graph showing standard length in millimeters $(\mathrm{mm})$ and weight in grams $(\mathrm{g})$ of juvenile shortnose suckers captured in Clear Lake, California (Modoc County) in 2012 and in Upper Klamath Lake (Klamath County) Oregon, from 2006 to 2010

\section{Tables}

Table 1. Number of trap nets set each week in Clear Lake from July 19 to August 15 and from September 24 to 26, 2012, using trap nets set overnight.

Table 2. Weekly catch per unit effort (number of juvenile suckers captured per number of trap nets

set each week) in Clear Lake from July 19 to August 15 and from September 24 to 26, 2012.

Table 3. Percentage of agreement in the number of annuli between two structures used to age juvenile suckers collected from Clear Lake, California, and its tributaries in 2012

Table 4. Parameter estimates for power curves (that is, weight $=a^{*}$ length ${ }^{b}$ ) fit to length-weight data collected on sacrificed juvenile suckers captured in Clear Lake in 2012, sacrificed juvenile suckers captured in Upper Klamath Lake in 2006 and from 2008 to 2010, and with live unidentified juvenile suckers captured at the fish evaluation station at the outlet of Upper Klamath Lake in 2012 (Bureau of Reclamation, unpub. data, 2013)

Table 5. Percentage of age- 0 and age- 1 suckers captured in Clear Lake, California and its tributaries in 2012, with afflictions. 
Conversion Factors, Datum, and Abbreviations and Acronyms

Conversion Factors

\begin{tabular}{lcl}
\hline \multicolumn{1}{c}{ Multiply } & By & To obtain \\
\hline millimeter (mm) & Length & \\
meter (m) & 0.03937 & inch (in. ) \\
kilometer (km) & 3.281 & foot (ft) \\
kilometer (km) & 0.6214 & mile (mi) \\
meter (m) & 0.54 & mile, nautical (nmi) \\
\hline & 1.094 & yard (yd) \\
\hline hectares (ha) & Area & \\
\hline & 2.47 & acres (ac) \\
\hline gram (g) & Mass & \\
\hline
\end{tabular}

Temperature in degrees Celsius $\left({ }^{\circ} \mathrm{C}\right)$ may be converted to degrees Fahrenheit $\left({ }^{\circ} \mathrm{F}\right)$ as follows:

$$
{ }^{\circ} \mathrm{F}=\left(1.8 x^{\circ} \mathrm{C}\right)+32 \text {. }
$$

\section{Datum}

Horizontal coordinate information is referenced to the North American Datum of 1983 (NAD 83).

\section{Abbreviations and Acronyms}

\begin{tabular}{ll}
\hline \multicolumn{1}{c}{ Abbreviations } & \multicolumn{1}{c}{ Meaning } \\
\hline AFA & Aphanizomenon flos-aquae \\
CPUE & catch per unit effort \\
FL & fork length \\
PIT & passive integrated transponder \\
SL & standard length \\
Reclamation & Bureau of Reclamation \\
USGS & U.S. Geological Survey \\
$W_{r}$ & relative weight \\
\hline
\end{tabular}




\section{Age and Condition of Juvenile Catostomids in Clear Lake Reservoir, California}

By Summer M. Burdick, U.S. Geological Survey, and Josh Rasmussen, U.S. Fish and Wildlife Service

\section{Executive Summary}

Although infrequent recruitment of new individuals into the adult spawning populations of Lost River suckers (Deltistes luxatus) and shortnose suckers (Chasmistes brevirostris) limits recovery of these species in Upper Klamath Lake, it is not clear that populations are recruitment limited in Clear Lake Reservoir (hereafter Clear Lake). Specifically, some evidence indicates that shortnose suckers may regularly recruit to the adult spawning population in Clear Lake. Therefore, a study of early life history patterns and recruitment dynamics in Clear Lake may lead to a better understanding of what is limiting recovery of suckers in both lakes. Adult suckers in Clear Lake migrate up Willow Creek and its tributaries to spawn in some years, but low flow in Willow Creek may inhibit spawning migrations in other years. It is unclear whether spawning is successful, larvae survive, or how frequently juveniles persist to adulthood. Environmental variables associated with successful spawning or young-of-year survival have not been identified, and early life history for these populations is poorly understood. The U.S. Geological Survey, in cooperation with the U.S. Fish and Wildlife Service, initiated a study in 2011 to better understand juvenile sucker life history in Clear Lake, and to identify constraints in the early life history that may limit recruitment to the adult spawning populations. The relative weights of shortnose suckers from Clear Lake and Upper Klamath Lake were compared to examine differences in condition. However, it is unclear whether the disparity in relative weights between the populations reflects differences in condition, phenotype, or both. Approximately 80 percent of juvenile suckers in Clear Lake are shortnose suckers with some morphologic features similar to Klamath largescale suckers (Catostomus snyderi), whereas juvenile suckers in Upper Klamath Lake can be clearly classified as either shortnose or Lost River suckers. The presence of juvenile suckers age-3 and older indicate that production, larval survival, and juvenile survival are at least periodically sufficient to lead to recruitment into the adult population of shortnose suckers in Clear Lake. 


\section{Introduction}

Lost River sucker (Deltistes luxatus) and shortnose sucker (Chasmistes

brevirostris) are endemic to the Upper Klamath Basin of northern California and southern Oregon, where they were both abundant historically. Since the 1920s, several populations and spawning subpopulations were extirpated throughout the range of these species (National Research Council, 2004). Decreases in Upper Klamath Lake (Klamath County, Oregon) populations were noted beginning in the 1960s, eventually leading to their federal listing as endangered in 1988 under the Endangered Species Act of 1973, as amended (U.S. Fish and Wildlife Service, 1988). Clear Lake (Modoc County, California), Upper Klamath Lake, and the tributaries of both lakes are designated as critical habitat for Lost River and shortnose suckers (U.S. Fish and Wildlife Service, 2012, 2013).

Poor recruitment into adult spawning populations is one of several reasons cited for the continued decline and lack of recovery in Upper Klamath Lake sucker populations (National Research Council, 2004). It is not clear, however, whether these species are recruitment limited in Clear Lake, particularly the shortnose sucker (D.A. Hewitt and E.C. Janney, U.S. Geological Survey [USGS], written commun., 2011). Consistently high mortality, relative to natural levels, at approximately 5-7 months of age (AugustOctober) is thought to lead to poor recruitment into Upper Klamath Lake adult sucker populations (Burdick and others, 2009). A 1995 cohort of suckers (species unknown) in Clear Lake continued to be detectable a year later in 1996, indicating that these fish survived longer than is typical in Upper Klamath Lake (U.S. Geological Survey, unpub. data, 1996). It is not clear from the limited data collected, however, if first year survival is typical, or if the 1995 cohort is an anomaly.

Apparent cohorts of smaller Lost River suckers (about 300-400 mm fork length (FL)) were evident in annual autumn sampling in Clear Lake from 2005 to 2008, but these fish did not appear to survive in subsequent years (D.A. Hewitt and E.C. Janney, U.S. Geological Survey, written commun., 2011). Length frequency data indicate somewhat regular recruitment of shortnose suckers to the adult spawning population, based on a broad distribution of lengths in the captured individuals greater than $300 \mathrm{~mm}$ FL. However, length is a relatively poor surrogate for age of shortnose suckers in Clear Lake, which causes uncertainty about the interpretation of length-frequency plots for this species (D.A. Hewitt and E.C. Janney, U.S. Geological Survey, written commun., 2011).

The Klamath largescale sucker (Catostomus snyderi) also occurs in Clear Lake and its tributaries and is believed to hybridize with the shortnose sucker. The identity of shortnose-like suckers in Clear Lake has been debated at least three times in the scientific literature since the late 1800s (summarized in Koch and others, 1975), and was most recently examined by Markle and others (2005). Markle and others (2005) concluded that (1) shortnose and Klamath largescale suckers exist in Clear Lake, (2) the two species are more similar in Clear Lake than in other parts of their range, and (3) the two species are difficult to distinguish as juveniles. The latter is confirmed by USGS passive integrated transponder (PIT) tag data, in which fish tagged at less than $350 \mathrm{~mm}$ standard length (SL) were sometimes identified as Klamath largescale suckers when tagged, and as shortnose suckers when recaptured a year or two later (U.S. Geological Survey, unpub. data, 2011). 
Using the characteristics described by Markle and others (2005), USGS crews identified about 59 percent of adult suckers captured in autumn trammel net sampling as shortnose suckers, and only18 percent as Klamath largescale suckers (Barry and others, 2009). However, no quantitative/objective methods of distinguishing the species currently exist, and identifications are largely based on subjective assessment of nuanced morphological character traits.

A combination of PIT tag and telemetry data are useful for describing the spawning runs of Lost River and shortnose suckers from Clear Lake. Both species initiate spawning runs up Willow Creek on the ascending limb of the hydrograph at water temperatures between 5 and $6{ }^{\circ} \mathrm{C}$, which typically occur in late February or early March (Barry and others, 2009). Telemetry data collected in 2011 indicate that Willow Creek and its major tributary Boles Creek were the only locations that Clear Lake suckers spawn (U.S. Geological Survey, unpub. data, 2011). The magnitude and duration of spawning runs are larger in years with high Willow Creek discharge (Barry and others, 2009). Low flow in Willow Creek appears to severely limit spawning migrations in some years (Barry and others, 2009). However, the precise nature of the relation between discharge and the number of fish that ascend Willow Creek to spawn is unknown because there is no flow gage in Willow Creek. Furthermore, it is unclear if suckers forgo spawning in years of low flow, or if they spawn in an alternative location. Telemetry data indicate that Lost River suckers are restricted to the mainstem of Willow Creek, whereas shortnose suckers travel up smaller tributaries to Willow Creek (U.S. Geological Survey, unpub. data, 2011). Spawning migrations appear to cease when Willow Creek water temperatures reach $10^{\circ} \mathrm{C}$, which typically occurs in mid-April (Barry and others, 2009).

Less is known about the early life history of suckers in Clear Lake than about their spawning migrations. In 1993, Lost River suckers out-migrated as larvae from April 18 to June 1 and shortnose suckers out-migrated as both larvae and juveniles from April 20 until late July (Scoppettone and others, 1995). Diurnal samples were not collected for comparison, but nocturnal migration behavior is consistent with out-migrating larvae in the Williamson River, a tributary to Upper Klamath Lake (Cooperman and Markle, 2003). Basic data such as water temperature and stream flow data for Willow Creek are lacking from 1993, and larval catch data are only available for a single year, so it is impossible to tell if the out-migration of larvae is related to these environmental variables. Collection of juvenile and adult suckers from Willow Creek at the Forest Service Road 48N08 crossing in August 1995 suggests that a resident or fluvial life history form may be using this tributary to Clear Lake (Perkins and Scoppettone, 1996). However, Perkins and Scoppettone (1996) did not record the species of sucker they observed. Given that Klamath largescale suckers occupy the system and are known to be fluvial, it is possible that the captured fish were not one of the endangered suckers.

There are two goals for the research reported on in this document: (1) better understand juvenile sucker life history in Clear Lake and (2) identify constraints if any in the early life history that may be limiting recruitment to the adult spawning populations in Clear Lake. 


\section{Description of Study Area}

Clear Lake was historically a natural lake covering about 6,500 ha with an associated marshy area to the east through which the main tributary (Willow Creek) flowed. This marshy area was permanently inundated, expanding the lake by about 3,900 ha, in 1910 when the Bureau of Reclamation built a dam on the Lost River near its outlet producing a coterminous water body with western and eastern lobes (Buettner and Scoppettone, 1991). The Clear Lake watershed is arid high desert and is almost entirely publicly owned. The lake itself is owned by the U.S. Fish and Wildlife Service's Clear Lake National Wildlife Refuge (established in 1911), but the upper watershed is part of the U.S. Forest Service's Modoc National Forest. The area immediately surrounding Clear Lake is rocky with sagebrush (Artemesia spp.) steppe plant communities and western juniper (Juniperus occidentalis), although the upper watershed is populated with ponderosa pine (Pinus ponderosa) (Buettner and Scoppettone, 1991). Water depth in the western lobe of the lake can be as deep as $4 \mathrm{~m}$ but is less than $2 \mathrm{~m}$ deep in the eastern lobe at full pool. Substrate consists mostly of sand and fines, with lava rock boulders scattered throughout the lake. Clear Lake is very turbid, which is likely the result of wind coupled with shallow water. These conditions appear to prevent the large-scale algae blooms that occur annually on Upper Klamath Lake. The most apparent species of algae in Clear Lake is the presumably non-toxic Aphanizomenon flos-aquae (AFA). A bloom of a potentially toxin producing Microcystis sp. was reported by Buettner and Scoppettone (1991) in July 1989, but it is unclear if the algal species was correctly identified.

Two creeks in the basin provide spawning habitat for suckers. Willow Creek, the main tributary to Clear Lake, is a perennial stream that enters at the northwestern shore near the dam. Boles Creek joins Willow Creek less than $1 \mathrm{~km}$ upstream of Clear Lake and is a low gradient intermittent stream. Downstream of Boles Creek, Willow Creek is "very wide with large boulders interspersed with cobble and gravel," and upstream of Boles Creek, Willow Creek is "steep and narrow with fine to coarse gravels and occasional reaches of solid lava rock" (Buettner and Scoppettone, 1991). There are numerous small earthen dams that create small stock ponds in Willow and Boles Creeks. The status of these dams as migration barriers to suckers is presently unknown. Spawning is known to occur in Willow and Boles Creeks, but has not been documented in Mowitz Creek, a small intermittent stream that enters Clear Lake at the southern end of the eastern lobe.

\section{Methods}

Suckers were sampled using trap nets in Clear Lake between July 19 and August 15 and again between September 24 and 26, 2012. Samples sites were located in one of three areas along shorelines in the western lobe of the lake (fig. 1) based on knowledge of juvenile sucker distribution from previous efforts (Burdick and Rasmussen, 2012). The numbers of nets set in each shoreline area range from 0 to 15 , and are given by week in table 1. Two additional sample sites were located in Boles Creek and one additional site was located in Willow Creek near the mouth of Mammoth Springs (fig. 1). Trap nets were rectangular with mouth dimensions of $0.609 \times 0.914 \mathrm{~m}$, a $10-\mathrm{m}$ lead, and three internal fykes. These nets were green with 6.4-mm mesh, nylon netting. Nets were set 
between 0739 and 1533 hours and pulled the next day between 0750 and 1529 hours for a target soak time of 20 hours. A backpack mounted electrofishing unit was used to sample suckers in Boles Creek. Four electrofishing surveys, lasting between 20 and 75 minutes each, were completed. A survey was conducted both upstream and downstream of Modoc County Road 136 and upstream and downstream of the Forest Service Road 46 crossings with Boles Creek.

Parasites that could be observed without magnification, SL, FL, deformities, or any afflictions or abnormalities were recorded for each sucker. Approximately one-third of untagged suckers less than $100 \mathrm{~mm}$ SL were sacrificed by an overdose of MS-222 then preserved in buffered formalin. Sacrificed suckers were identified to species using methods described by Markle and others (2005), which involves counting vertebrae and gill rakers, and examining lip morphology. Anatomy was imaged using a mammography machine to obtain vertebral counts. Sacrificed suckers were weighed to the nearest tenth of a gram and lapillus otoliths and opercles were removed for aging. Following the examples of Koch and others (1975) and Buettner and Scoppettone (1991), but in contrast to Andreasen (1975), we refer to fish that have characteristics of shortnose and Klamath largescale suckers from Clear Lake as shortnose suckers rather than Klamath largescale suckers or hybrids.

Captured suckers were either PIT tagged or a fin ray was removed. This was done to limit the amount of stress inflicted on the animal to a single invasive procedure (that is, tagging or fin clipping). Suckers equal to or greater than $70 \mathrm{~mm}$ SL were given a PIT tag and released alive at the site of capture when water temperatures were less than $20^{\circ} \mathrm{C}$ (Burdick, 2011). Complete pectoral fin rays were removed for aging by cutting as close to the fin base as possible. Sections were taken from the proximal end of the fin ray and read under transmitted light at 5-10× magnification.

Fin rays from all suckers and all three calcified structures from sacrificed suckers were examined to estimate age. Fin rays were mounted in epoxy, sectioned, and viewed by two technicians under magnification using transmitted light to estimate age. The number of annuli was first determined in blind reads, with each technician having no knowledge of the other's total annuli count. When there was a discrepancy in the number of annuli, technicians examined fin rays together and came to a consensus about the estimated age of each fish. Flesh was removed from opercles and structures were examined without preparation using transmitted light. Lapillus otoliths were mounted on glass slides, sanded to the core, flipped and sanded again until annuli could be clearly counted. A single technician read all opercles and otoliths.

We compared the slope of the length weight relation between sacrificed juvenile shortnose suckers captured in Clear Lake in 2012 with sacrificed juvenile shortnose suckers captured in Upper Klamath Lake in 2006 and from 2008 to 2010, and with live caught unidentified juvenile suckers captured at the fish evaluation station at the outlet of Upper Klamath Lake in 2012 (Bureau of Reclamation, unpub. data, 2013). Due to wind and wave action, in-field weight data collected for fish from Clear Lake in 2011 were inaccurate. Therefore we did not compare weight data between Clear Lake suckers collected in 2011 and 2012. Linear models were fit to log transformed length and weight data and slopes were compared using ANOVA in program R (R Core Team 2012). Power curves (that is, Weight $=$ Constant $*$ length $^{\text {slope }}$ ) were fit to data from each year using the 
$n l s L M$ function in program $\mathrm{R}$ for display and reporting purposes and parameter estimates and their 95 percent confidence intervals are reported.

The relative weight $\left(W_{r}\right)$ of sacrificed shortnose suckers captured in Clear Lake in 2012 was calculated as the weight for each individual divided by the predicted weight for its SL, based on a length-weight relationship estimated from 1,013 juvenile shortnose suckers captured in Upper Klamath Lake from 2006 to 2010 (Burdick and others, 2007; U.S. Geological Survey, unpub. data, 2010), and multiplied by 100 (Anderson and Neumann, 1996). Therefore $W_{r}$ is scaled around 100, such that values less than 100 indicate relatively poor condition, and individuals with values greater than 100 are in relatively good condition, as compared to the expected weights of Upper Klamath Lake juvenile suckers of the same length.

\section{Results}

Trap net catch per unit effort (CPUE) ranged from 0.6 to 4.3 suckers per set in Clear Lake (table 2). Only one juvenile sucker was captured in 16 nets set in Willow Creek and no suckers were captured in 12 nets set in Boles Creek. A single $244 \mathrm{~mm}$ SL Klamath largescale sucker was captured using electrofishing in Boles Creek downstream of Forest Service Road 46. Juvenile sucker catch rates were slightly greater in most weeks on the South Shore compared to the West Shore and Bird Inlet (table 2).

A total of 72 juvenile suckers were sacrificed, 11 were found dead in our nets, and 3 died during handling. All of these fish were examined for species specific characteristics (that is, number of vertebrae, number of gill rakers, and lip morphology). Of these fish, 70 ( 81.4 percent) were identified as shortnose suckers, 9 (10.5 percent) were identified as Lost River suckers, and 7 (8.1 percent) had characteristics intermediate of shortnose, Lost River, and Klamath largescale suckers.

A total of 42 juvenile suckers (standard length 72-285 mm) were given $12 \mathrm{~mm}$ PIT tags. Four (9.5 percent) of the tags from these fish were redetected in 2012 on piscivorous bird colonies in the Clear Lake National Wildlife Refuge. Tags from two juvenile suckers tagged in 2011 also were detected in 2012. One of these, tagged in the western lobe of Clear Lake, was detected on a bird colony in the eastern lobe of Clear Lake. The other was recaptured on September 19, 2012, approximately $1.9 \mathrm{~km}$ north of where it was tagged on June 28, 2011.

The agreement in estimated ages between any two aging structures taken from sacrificed fish, all less than $100 \mathrm{~mm} \mathrm{SL}$, was at best 50 percent (table 3). When age estimates were compared between two structures, the vast majority (range was between 91 and 96 percent) were only different by 1 year. Opercles were most commonly assigned an age of 0 , whereas fin rays were most commonly assigned an age of 1 and otoliths were about equally as likely to be assigned the age of 0 or 1 . Annuli were most clearly identified on fin rays and length frequency data mostly supported fin ray estimated ages for the two youngest age classes (fig. 2). Age-2 and age-3 fish appeared to be indistinguishable based on length. Age- 4 and age- 5 suckers appeared to fall into distinct length bins, but our sample only contained seven fish with fin ray estimated ages in this range making conclusions about age and length relations tenuous (fig. 2). We used fin ray estimated ages in the rest of our analysis, based on length frequency and fin ray agreement, the clarity of annuli on fin rays, and the concern that formalin may have degraded opercles and otoliths. 
The number of annuli counted on fin rays ranged from 0 to 6 . Of the 384 juvenile suckers aged using fin rays, 17 percent were age- 0,61 percent were age- 1,17 percent were age-2, 3 percent were age-3, and the remainder were age- 4 to age- 6 . Of the 69 shortnose suckers that were sacrificed and aged with fin rays, 30 percent were estimated to be age- 0,58 percent were estimated to be age- 1 , and only 12 percent were estimated to be age-2. Standard length but not age data were collected for 59 suckers because they were tagged and released or the quality of the fin ray was insufficient to obtain an age estimate. The length frequency of un-aged fish was similar to those that were aged, indicating that aged fish were representative of all captured suckers (fig. 3).

Age-0 suckers appeared to grow faster than age- 1 suckers. The median standard length of age- 0 suckers increased by an average of $7.8 \mathrm{~mm}$ per week from the week of July 22 to the week of August 5. The median age-0 standard length then decreased during the week of August 12. In contrast, the median standard length of suckers with fin ray estimated ages of 1 increased by an average of $3.2 \mathrm{~mm}$ per week from the week of July 22 to the week of August 12. This resulted in overlapping length frequency distributions for these age classes by the week of July 29 (fig. 4). Too few suckers were identified as Lost River suckers to determine differences in growth among species.

Juvenile shortnose suckers captured in Clear Lake in $2012(n=84)$ weighed less given their length than juvenile shortnose suckers captured in Upper Klamath Lake between 2006 and $2010(n=1,013)$ and juvenile suckers that were not identified to species at the fish evaluation station in $2012(\mathrm{n}=466$; $\mathrm{p}<0.001)$ (Bureau of Reclamation, unpub. data, 2013)(table 4; fig. 5). This was particularly true for the smallest suckers. However, power curves fit to length-weight data indicate that Clear Lake shortnose suckers gained weight more rapidly in proportion to their length when compared to suckers from Upper Klamath Lake (table 4; fig. 5), that is, the estimated slope or exponent is greater. When compared to Upper Klamath Lake shortnose suckers captured from 2006 to 2010, only 1 of 70 sacrificed juvenile shortnose suckers captured in Clear Lake in 2012 had a relative weight greater than 100. This was the only fish that weighed more given its length than an average fish of a similar length collected in Upper Klamath Lake prior to 2011.

With the exception of parasitic infections by adult female anchor worms, juvenile suckers captured in Clear Lake in 2012 had few afflictions (table 5). Twenty-eight percent of age- 0 and 36 percent of age- 1 suckers were parasitized by at least one adult female anchor worm (Lernaea cyprinacea), but none had more than three anchor worms. Four percent of age- 0 suckers and 12 percent of age- 1 suckers had skin abrasions or other infectious wounds. Other afflictions such as bulging, missing, or foggy eyes, split or damaged fins, opercle deformities, and parasites other than anchor worms were uncommon for juvenile suckers from Clear Lake in 2012 (table 5). 


\section{Discussion}

The species composition of juvenile suckers captured in trap nets was similar to adult suckers captured in trammel net surveys, indicating that shortnose suckers are the dominant sucker species in Clear Lake, with Lost River suckers being much less common. Shortnose suckers made up 81 percent of sacrificed juvenile suckers collected from Clear Lake in 2012 and 78 percent in 2011 (Burdick and Rasmussen, 2012). Adult suckers captured in Clear Lake in 2011 and 2012 are composed of about 81 percent shortnose suckers and 16 percent Lost River suckers (U.S. Geological Survey, unpub. data, 2012). Lost River suckers made up 8 percent of sacrificed juvenile suckers in 2012 but were not detected at all in 2011. The lack of Lost River suckers in 2011 probably is the result of their rarity and the small sample size of fish sacrificed for species identification.

Although the lack of agreement in the number of annuli found on age structures indicates poor precision of age estimates, age estimates from fin rays do not appear to be biased. The high number of opercles with no annuli may be due to preservation in formalin. Formalin tends to degrade calcified structures and may have had a more direct effect on opercles that are located closer to the exterior of the body compared to otoliths that were protected by the skull or fin rays that were removed prior to fish preservation (G. Scoppettone, U.S. Geological Survey, oral commun., 2013). The annuli clarity on fin rays was much better than on opercles or otoliths. Additionally, a comparison between length frequency data and fin ray ages indicates that estimated ages based on fin rays are relatively unbiased. Due to some overlap in lengths among age classes, particularly in August samples, length is an unreliable indicator of sucker age. Because of the suspected lack of precision in fin ray age data, these data are useful for descriptions of age distribution but are inappropriate for examining effects on specific cohorts or estimating mortality rates.

Juvenile sucker catches in 2012 were comprised predominantly of age- 1 fish. This is most likely due to more favorable spawning conditions (that is, higher flows) in Willow Creek in 2011 compared to 2012. This is evidenced by the much greater number of PIT tagged adult suckers detected ascending Willow Creek during annual spawning migration monitoring in 2011 (3,147) than in 2012 (604; U.S. Geological Survey, unpub. data, 2013). Other potential explanations for higher catches of age- 1 compared to age- 0 suckers include delayed recruitment of age-0 suckers into sampling gear or into the sampled habitats. We commonly capture age-0 suckers less than $40 \mathrm{~mm}$ SL using trap nets in Upper Klamath Lake, therefore it is unlikely that the gear limited catches of small suckers in Clear Lake (Bottcher and Burdick, 2010). Because trap net sampling was restricted to the western lobe of Clear Lake and spawning occurs in tributaries that enter the eastern lobe, it is possible that suckers were not fully dispersed into the sampled area until they were a year old. However, in 2011 catches of age- 0 suckers were four times that of age- 1 suckers indicating that age- 0 catches were not limited by dispersal into the western lobe but rather reflected the substantial production in 2011 and very low production in 2010 (Burdick and Rasmussen, 2012).

The lack of captures of larger and older individuals indicate that age-1 and older suckers in Clear Lake experienced mortality, reduced selectivity as they aged, or a combination of both. Reduced selectivity for suckers approximately 300 to $400 \mathrm{~mm} F \mathrm{FL}$ is confirmed by the presence of these individuals in annual trammel net sampling that 
targets adult suckers (U.S. Geological Survey, unpub. data, 2013). Because age specific selectivity and mortality are confounded, there is variability in annual production, and uncertainty in age estimates, the rate of mortality cannot be estimated from these data using traditional catch curve methods. In both Clear and Upper Klamath Lakes, the decrease in catch rates of age- 1 and age- 3 suckers indicate mortality is on the same order of magnitude but, more age- 3 and older juvenile suckers were captured in Clear Lake than in Upper Klamath Lake. In Clear Lake, 17 juvenile suckers estimated to be age-3 or older based on fin rays and length were captured in 2012 for a catch rate of 0.083 suckers per net. Whereas, only 4 juvenile suckers estimated to be age-3 or older based on length were captured from 2007 to 2009 in Upper Klamath Lake for a catch rate of 0.001 suckers per net (U.S. Geological Survey, unpub. data, 2013). The number of older juvenile suckers captured in Clear Lake may indicate production, larval survival, youngof-year survival or a combination of these factors are better in Clear Lake than in Upper Klamath Lake.

It is unclear whether the disparity in relative weights among the groups we examined reflects differences in condition, phenotype, or both. Shortnose suckers in Clear Lake generally exhibit external morphological characteristics intermediate to shortnose suckers and Klamath largescale suckers in Upper Klamath Lake (Markle and others, 2005). The fact that juvenile shortnose suckers in Clear Lake apparently weigh less at any given length than similar individuals in Upper Klamath Lake may be further evidence of these phenotypical differences. Given that individuals from Clear Lake did not exhibit any clear signs of poor condition, it is likely these differences are due to some phenotypic reason, whether genetic or environmental.

Age- 0 and age- 1 suckers were parasitized by female anchor worms in both Clear and Upper Klamath Lakes, but the number of anchor worms per fish was not a cause for concern in either lake. Twenty-eight percent of age- 0 and 36 percent of age- 1 suckers captured in Clear Lake in 2012 were parasitized by at least one adult female anchor worm. Rates of anchor worm parasitism were lower in Clear Lake in 2011 when 16 percent of age- 0 suckers and two of five age- 1 suckers had anchor worms. The annual rate of anchor worm infection was no greater than 18 percent on putative age- 0 suckers and was between 20 and 50 percent on putative age-1 suckers collected from Upper Klamath Lake between 2008 and 2010 (Burdick and others, 2009; Bottcher and Burdick, 2010; Burdick and VanderKooi, 2010; Burdick, 2012). Juvenile suckers from Clear Lake had no more than three anchor worms per infected fish. The vast majority of parasitized age- 0 and about one-third of parasitized age- 1 suckers examined from Upper Klamath Lake from 2008 to 2010 had only one anchor worm attached, but as many as 18 anchor worms have been recorded on an age-1 sucker from Upper Klamath Lake (Burdick, 2012). The prevalence and intensity of anchor worm parasitism may not be cause for alarm (Robinson and others, 1998). Some evidence suggests that anchor worm infections on their own do not pose serious threats to overall fish health (Robinson and others, 1998). However, secondary infection may occur where anchor worms attach to the fish (Robinson and others, 1998). 
Deformed opercles were somewhat common on juvenile suckers captured in Upper Klamath Lake from 2008 to 2010 but were only detected on one age- 0 and one age-1 sucker collected from Clear Lake in 2012 and on 3 percent of juvenile suckers from Clear Lake in 2011. In Upper Klamath Lake, up to 18 percent of putative age- 0 and up to 9 percent of putative age-1 suckers have short or malformed opercles (Burdick and others, 2009; Bottcher and Burdick, 2010; Burdick and VanderKooi, 2010; Burdick, 2012). The frequency of deformed opercles in Clear Lake is more consistent with rates of this deformity observed in the early 1990s in Upper Klamath Lake, when 4.7 percent of Lost River suckers and 1.4-3.1 percent of shortnose suckers exhibited opercle deformities (Plunkett and Snyder-Conn, U.S. Fish and Wildlife Service, written commun., 2000). It is important to determine why opercle deformities are different among the two lakes because they have been shown to lower resistance to oxygen stress and predispose fish to infections by bacteria, parasites, and fungi (Galeotti and others, 2000; Beraldo and others, 2003). Although these deformities are common in hatchery raised fish and considered non-lethal, deformed opercles in combination with extended periods of low dissolved oxygen concentrations and abundant parasites may be lethal combination for age-0 suckers in Upper Klamath Lake.

In summary, the sucker community in Clear Lake is dominated by shortnose sucker, but both federally listed species do produce viable young each year. Production is apparently variable from year to year, but our efforts here are not able to quantify the juvenile survival and subsequent recruitment rates to the adult populations in Clear Lake. Juveniles of shortnose sucker tend to be heavier at a given length in Upper Klamath Lake, compared to Clear Lake; they also have higher rates of opercle deformities but similar rates of parasitism. These differences may provide clues about the cause of limited recruitment to the adult spawning populations, but we did not identify specific constraints. Continued comparisons of ecology and life history between these two populations of these species will be very useful in furthering our understanding of the problems facing each population.

\section{Acknowledgments}

This project was funded by Ruby Pipeline L.L.C. Corporation (El Paso, Tex.). Data were collected with the help of Amari Dolan-Caret, Elizabeth Ng, Travis Ciotti, Raefield Benson, and Jesse Kane (all of the U.S. Geological Survey). Alta Harris and Amari Dolan-Caret (both of the U.S. Geological Survey) developed and manage the database used in this research. 


\section{References Cited}

Anderson, R.O., and Neumann, R.M., 1996, Length, weight, and associated structural indices, in Murphy, B.R., and Willis, D.W., Fisheries Techniques (2nd ed.): Bethesda, Maryland, American Fisheries Society, p. 447-482.

Andreasen, J.K., 1975, Systematics and status of the Family Catostomidae in southern Oregon: Corvallis, Oregon State University, Ph.D. thesis, $80 \mathrm{p}$.

Barry, P.M., Janney, E.C., Hewitt, D.A., Hayes, B.S., and Scott, A.C., 2009, Population dynamics of adult Lost River (Deltistes luxatus) and shortnose (Chasmistes

brevirostris) suckers in Clear Lake Reservoir, California, 2006-08: U.S. Geological Survey Open-File Report 2009-1109, 18 p. (Also available at http://pubs.usgs.gov/of/2009/1109/.)

Beraldo, P., Pinosa, M., Tibaldi, E., and Canavese, B., 2003, Abnormalities of the operculum in gilthead sea bream (Sparus aurata)-Morphological description: Aquaculture, v. 220, p. 89-99.

Bottcher, J., and Burdick, S.M., 2010, Temporal and spatial distribution of endangered juvenile Lost River and shortnose suckers in relation to environmental variables in Upper Klamath Lake, Oregon - 2009 annual data summary: U.S. Geological Survey Open-File Report 2010-1261, 42 p. (Also available at http://pubs.usgs.gov/of/2010/1261/.)

Buettner, M.E., and Scoppettone, G.G., 1991, Distribution and information on the taxonomic status of the shortnose sucker (Chasmistes brevirostris) and Lost River sucker (Deltistes luxatus) in the Klamath River Basin, California: Reno, Nev., Seattle National Fishery Research Center, 34 p.

Burdick, S.M., 2011, Tag loss and short-term mortality associated with passive integrated transponder tagging of juvenile Lost River suckers: Transactions of the American Fisheries Society, v. 31, p. 1,088-1,092.

Burdick, S.M., 2012, Distribution and condition of larval and juvenile Lost River and shortnose suckers in the Williamson River Delta restoration project and Upper Klamath Lake, Oregon: 2010 annual data summary: U.S. Geological Survey Open-File Report 2012-1027, 38 p. (Also available at http://pubs.usgs.gov/of/2012/1027/.)

Burdick, S.M., Ottinger, C., Brown, D.T., VanderKooi, S.P., Robertson, L., and Iwanowicz, D., 2009, Distribution, health, and development of larval and juvenile Lost River and shortnose suckers in the Williamson River Delta restoration project and Upper Klamath Lake, Oregon—2008 annual data summary: U.S. Geological Survey Open-File Report 2009-1287, 76 p. (Also available at http://pubs.usgs.gov/of/2009/1287/.)

Burdick, S.M., and Rasmussen, J., 2012, Preliminary juvenile Lost River and shortnose sucker investigations in Clear Lake, California—2011 pilot study summary: U.S. Geological Survey Open-File Report 2012-1180, 18 p. (Also available at http://pubs.usgs.gov/of/2012/1180/.)

Burdick, S.M., and VanderKooi, S.P., 2010, Temporal and spatial distribution of endangered juvenile Lost River and shortnose suckers in relation to environmental variables in Upper Klamath Lake, Oregon-2008 annual data summary: U. S. Geological Survey Open-File Report 2010-1051, 36 p. (Also available at http://pubs.usgs.gov/of/2010/1051/.) 
Burdick, S.M., Wilkens, A.X., and VanderKooi, S.P., 2007, Near-shore and off-shore habitat use by endangered, juvenile Lost River and shortnose suckers in Upper Klamath Lake, Oregon-2006 data summary: U.S. Geological Survey Open-File Report 20071356, 38 p. (Also available at http://pubs.usgs.gov/of/2007/1356/.)

Cooperman, M.S., and Markle, D.F., 2003, Rapid out-migration of Lost River and shortnose suckers from in-river spawning beds to in-lake rearing grounds: Transactions of the American Fisheries Society, v. 132, p. 1,138-1,153.

Galeotti, M., Beraldo, P., de Dominis, S., D’Angelo, L., Ballestrazzi, R., Musetti, R., Pizzoloito, S., and Pinosam, M., 2000, A preliminary histological and ultrastructural study of opercular anomalies in gilthead sea bream larvae (Sparus aurata): Fish Physiology and Biochemistry, v. 22, p. 151-157.

Koch, D.L., Cooper, J.J., Contreras, G.P., and King, V., 1975, Survey of the fishes of the Clear Lake Reservoir Drainage: Reno, Nev., Center for Water Resources Research, 38 p.

Markle, D.F., Cavalluzzi, M.R., and Simon, D.C., 2005, Morphology and taxonomy of Klamath Basin suckers (Catostomidae): Western North American Naturalist, v. 65, p. 473-489.

National Research Council, 2004, Endangered and Threatened Fishes in the Klamath River Basin-Causes of Decline and Strategies for Recovery: Washington, D.C., The National Academies Press, 398 p.

Perkins, F.L., and Scoppettone, G.G., 1996, Spawning and migration of Lost River suckers (Deltistes luxatus) and shortnose suckers (Chasmistes brevirostris) in the Clear Lake drainage, Modoc County, California: Reno, Nev., Final Report to the California Department of Fish and Game, $51 \mathrm{p}$.

R Core Team, 2012, R: A language and environment for statistical computing. $\mathrm{R}$ Foundation for Statistical Computing, Vienna, Austria, http://www.R-project.org/.

Robinson, A.T., Hines, P.P., Sorensen, J.A., and Bryan, S.B., 1998, Parasites and fish health in a desert stream, and management implications for two endangered species: North American Journal of Fisheries Management, v. 18, p. 599-608.

Scoppettone, G.G, Shea, S., and Buettner, M.E., 1995, Information on population dynamics and life history of shortnose suckers (Chasmistes brevirostris) and Lost River suckers (Deltistes luxatus) in Tule and Clear Lakes: Reno, Nev., National Biological Service, $80 \mathrm{p}$.

U.S. Fish and Wildlife Service, 1988, Endangered and threatened wildlife and plantsDetermination of endangered status for the shortnose sucker and Lost River sucker: Federal Register, v. 53, p. 27,130-27,134.

U.S. Fish and Wildlife Service, 2012, Designation of critical habitat for Lost River sucker and shortnose sucker Proposed Rule: Federal Register, v. 77 p. 73,740-73,768.

U.S. Fish and Wildlife Service, 2013, Draft revised recovery plan for the Lost River sucker (Deltistes luxatus) and shortnose sucker (Chasmistes brevirostris): U.S. Fish and Wildlife Service, Pacific Southwest Region, Sacramento, Calif., xviii +122 p. 


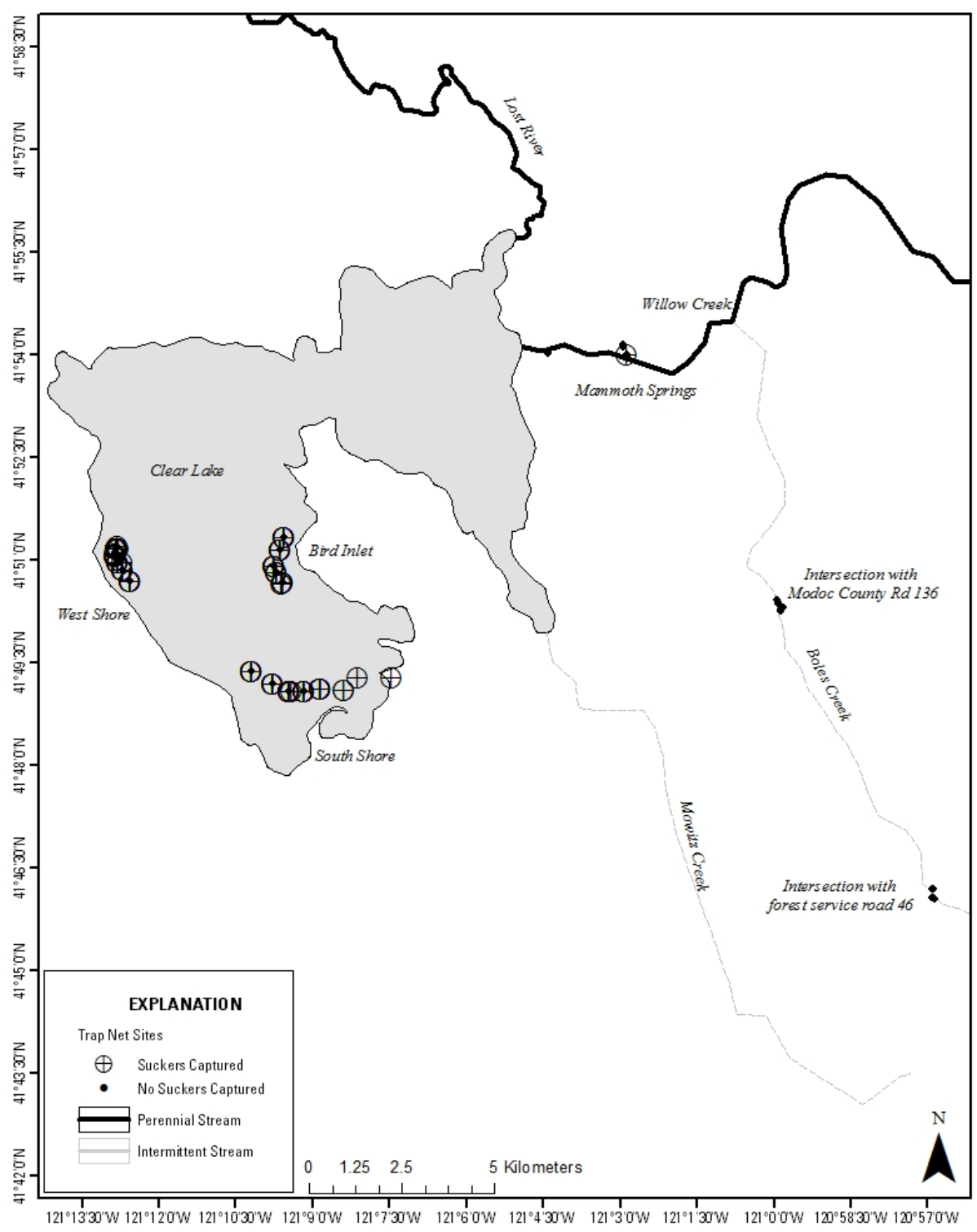

Figure 1. Map showing sampling locations in Clear Lake Reservoir, California (Modoc County), and its tributaries. The lake was sampled from July 19 to August 15 and from September 24 to 26, 2012, using trap nets set overnight. Electrofishing and trap netting also were conducted at the Modoc County Road 136 and Forest Service Road 46 crossings with Boles Creek. 


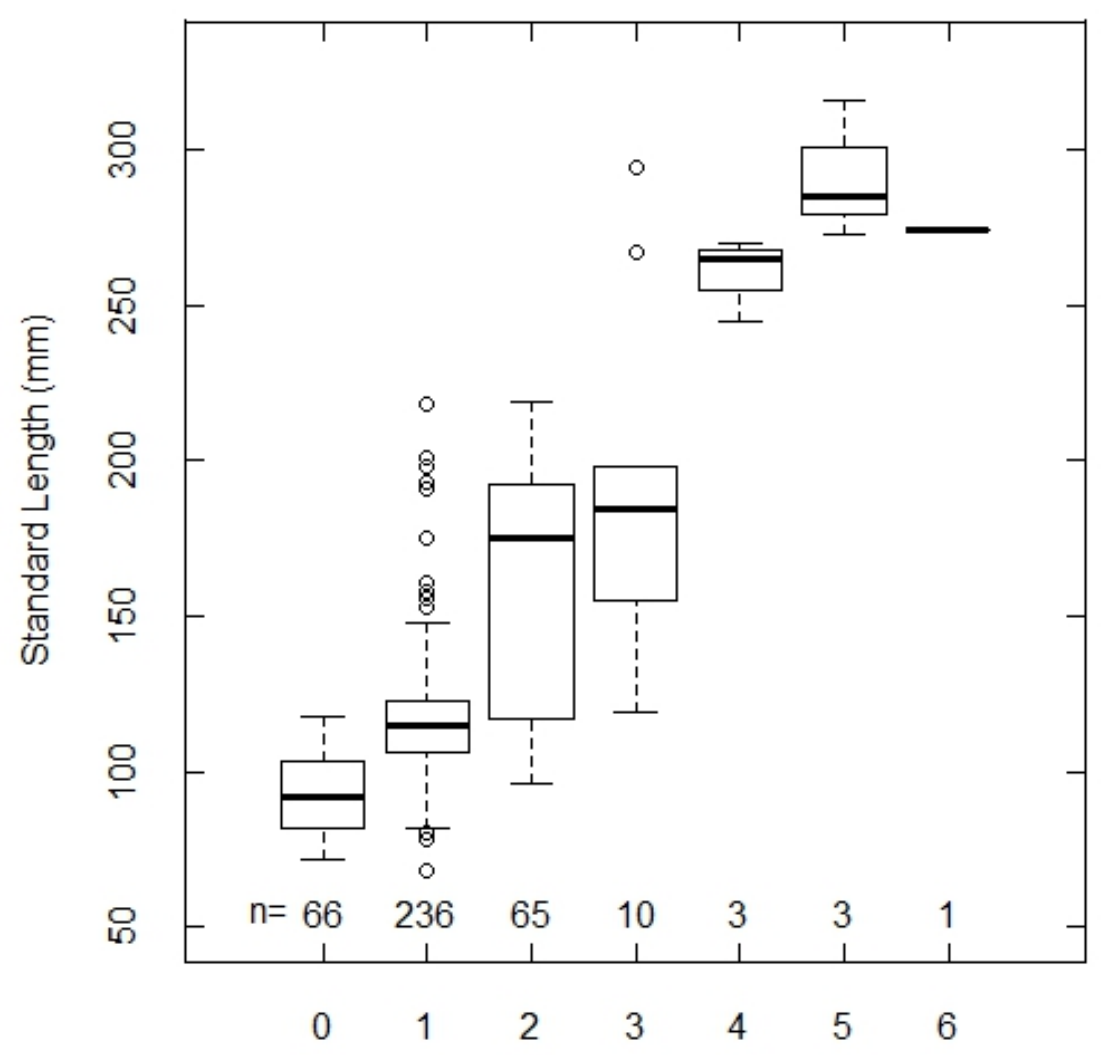

Total Fin Ray Annuli (Estimated Age in Years)

Figure 2. Boxplots showing standard length of suckers collected in Clear Lake, California (Modoc County) by annuli counted on fin rays. Boxplots show the 25th, 50th, and 75 th percentiles. Whiskers indicate the 10th and 90th percentiles and dots indicate outliers. The sample sizes used to create each box are given along the $x$-axis. 




Figure 3. Graph showing length frequency for juvenile suckers captured in Clear Lake, California (Modoc County) in 2012. Suckers that were aged using fin rays are shown in white and those that were not aged are shown in black. 




Figure 4. Graph showing weekly length frequency for juvenile suckers captured in Clear Lake, California (Modoc County) in 2012. The numbers of suckers captured each week are given in each panel. The median weekly length for age-0 suckers is shown with a black dot and for age-1 suckers with a black triangle. 


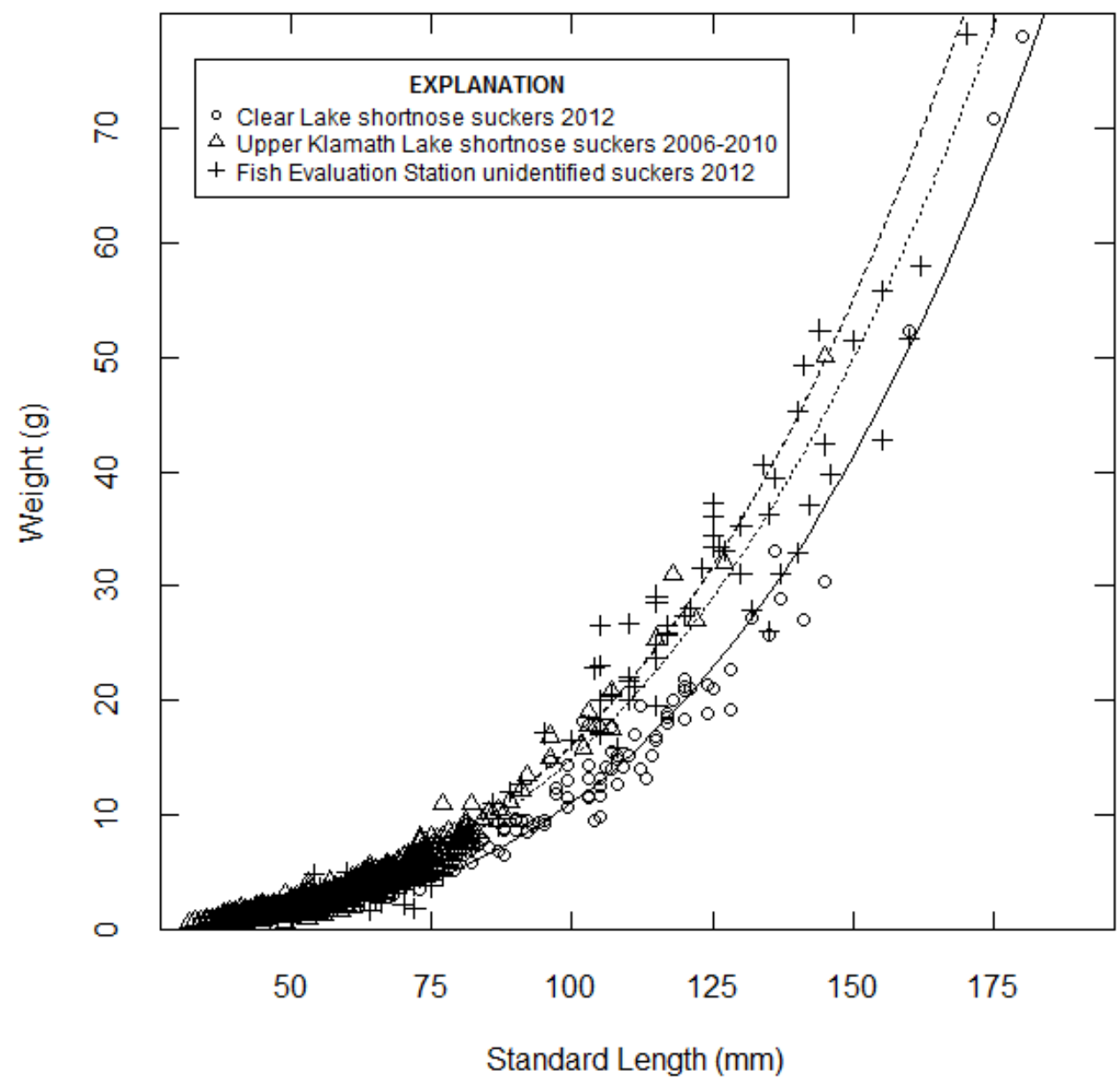

Figure 5. Graph showing standard length in millimeters $(\mathrm{mm})$ and weight in grams $(\mathrm{g})$ of juvenile shortnose suckers captured in Clear Lake, California (Modoc County) in 2012 and in Upper Klamath Lake (Klamath County) Oregon, from 2006 to 2010. Data also are shown for unidentified suckers captured in the Fish Evaluation Station near the outlet of Upper Klamath Lake in 2012 (Bureau of Reclamation, unpub. data, 2012). A fitted power curve (that is, Weight = Constant*LengthSlope) is shown for suckers captured in Clear Lake (solid), Upper Klamath Lake (dotted), and the Fish Evaluation Station at the outlet of Upper Klamath Lake (dashed). Confidence intervals for these curves are provided in table 4. 
Table 1. Number of trap nets set each week in Clear Lake from July 19 to August 15 and from September 24 to 26, 2012, using trap nets set overnight.

[Sampling locations are shown in figure 1]

\begin{tabular}{|c|c|c|c|c|c|c|c|}
\hline \multirow[b]{2}{*}{ Area } & \multicolumn{5}{|c|}{ Week } & \multirow[b]{2}{*}{ Sept 24} & \\
\hline & July 16 & July 23 & July 30 & Aug 6 & Aug 13 & & \\
\hline Bird Inlet & 5 & 15 & 15 & 15 & 15 & 0 & \\
\hline South Shore & 5 & 15 & 15 & 15 & 15 & 4 & \\
\hline West Shore & 5 & 15 & 15 & 15 & 15 & 6 & \\
\hline Total & & & & & & & 205 \\
\hline
\end{tabular}

Table 2. Weekly catch per unit effort (number of juvenile suckers captured per number of trap nets set each week) in Clear Lake from July 19 to August 15 and from September 24 to 26, 2012.

[Sampling locations are shown in figure 1]

\begin{tabular}{lrrrrrrr}
\hline & \multicolumn{7}{c}{ Week } \\
\cline { 2 - 7 } & Auly 16 & July 23 & July 30 & Aug 6 & Aug 13 & Sept 24 \\
\hline Bird Inlet & 0.8 & 1.6 & 1.1 & 0.7 & 1.3 & NA \\
South Shore & 2.0 & 2.1 & 2.9 & 3.8 & 4.3 & 3.3 \\
West Shore & 0.6 & 2.1 & 3.7 & 1.4 & 2.1 & 1.5 & \\
\hline Total & & & & & & & 2.2 \\
\hline
\end{tabular}

Table 3. Percentage of agreement in the number of annuli between two structures used to age juvenile suckers collected from Clear Lake, California, and its tributaries in 2012.

[Totals of 64 shortnose suckers and 14 suckers identified as either Lost River suckers or as suckers having characteristics intermediate of shortnose, Lost River, and Klamath largescale suckers were examined in the age analysis]

\begin{tabular}{lcc}
\hline & \multicolumn{2}{c}{ Percentage of agreement } \\
\cline { 2 - 3 } Structures & Shortnose suckers & Other suckers \\
\hline Opercles-Fin Rays & 42 & 43 \\
Otoliths - Fin Rays & 30 & 43 \\
Opercles - Otoliths & 33 & 50 \\
\hline
\end{tabular}


Table 4. Parameter estimates for power curves (that is, weight $=a^{*}$ length ${ }^{b}$ ) fit to length-weight data collected on sacrificed juvenile suckers captured in Clear Lake in 2012, sacrificed juvenile suckers captured in Upper Klamath Lake in 2006 and from 2008 to 2010, and with live caught unidentified juvenile suckers captured at the fish evaluation station at the outlet of Upper Klamath Lake in 2012 (Bureau of Reclamation, unpub. data, 2013).

\begin{tabular}{lcccc}
\hline \multicolumn{1}{c}{ Area } & a & $\begin{array}{c}\text { 95-percent confidence } \\
\text { Interval }\end{array}$ & b & $\begin{array}{c}\text { 95-percent } \\
\text { confidence Interval }\end{array}$ \\
\hline Clear Lake & $3.66 \mathrm{E}-06$ & $(2.05 \mathrm{e}-6-6.52 \mathrm{e}-6)$ & 3.24 & $(3.12-3.36)$ \\
Upper Klamath Lake & $1.45 \mathrm{E}-05$ & $(1.32 \mathrm{e}-5-1.60 \mathrm{e}-5)$ & 3.02 & $(3.00-3.04)$ \\
Fish Evaluation Station & $1.71 \mathrm{E}-05$ & $(1.31 \mathrm{e}-5-2.21 \mathrm{e}-5)$ & 2.97 & $(2.91-3.02)$ \\
\hline
\end{tabular}

Table 5. Percentage of age- 0 and age-1 suckers with afflictions captured in Clear Lake, California and its tributaries in 2012.

[Ages of suckers are based on the number of annuli counted on fin-ray sections]

\begin{tabular}{lcc}
\hline \multicolumn{1}{c}{ Affliction } & $\begin{array}{c}\text { Age-0 } \\
\text { (percent) }\end{array}$ & $\begin{array}{c}\text { Age-1 } \\
\text { (percent) }\end{array}$ \\
\hline Eyes bulging or missing & 0 & 1 \\
Damaged fins & 0 & 2 \\
Abrasions & 4 & 12 \\
Deformed opercles & $<1$ & $<1$ \\
Anchor worms & 28 & 36 \\
Lamprey & 1 & 3 \\
Other parasite & 1 & 0 \\
None & 65 & 50 \\
\hline
\end{tabular}


This page left intentionally blank 
Publishing support provided by the U.S. Geological Survey Publishing Network, Tacoma Publishing Service Center

For additional information contact:

Director, Western Fisheries Research Center

U.S. Geological Survey

6505 NE 65th Street

Seattle, Washington 98115

http://wfrc.usgs.gov/ 


\section{总}

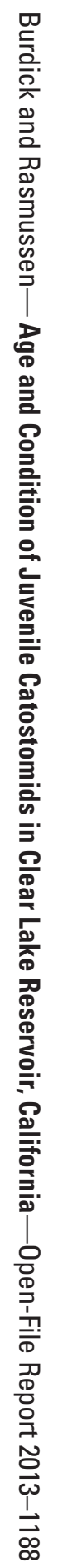

